\title{
PENGARUH PENAMBAHAN ANHIDRIDA MALEAT TERHADAP MUTU TEKNIS KARET ALAM TERMODIFIKASI
}

\author{
The Effect of Maleic Anhydride Addition to \\ Technical Quality of Modified Natural Rubber \\ Afrizal VACHLEPI* dan Mili PURBAYA \\ Balai Penelitian Sembawa - Pusat Penelitian Karet \\ Jalan Raya Palembang - Pangkalan Balai Km.29 Kotak Pos 1127 \\ Palembang 30001 Sumatera Selatan \\ *Email : a_vachlepi@yahoo.com
}

Diterima : 10 Mei 2019 / Disetujui : 14 Juni 2019

\begin{abstract}
The blending of natural rubber polymers with natural starch which has different properties and characteristics can produce polymers with new characteristics. Non-polar rubber polymers need to be modified so it can interact well with polar natural starch. The use of maleic anhydride can increase interaction with natural starch. The objectives of research were to study and obtain the best dosage using maleic anhydride additives in modifying the properties of natural rubber polymers. This dose was expected to produce modified natural rubber with different technical characteristics and quality so that it can be blended with natural starch. The treatments were the addition of maleated anhydride with a dose of $5 \%$ weight maleic per weight $(w / w)$ dry rubber, $10 \% \mathrm{w} / \mathrm{w}, 15 \% \mathrm{w} / \mathrm{w}$ and control (rubber without maleic anhydride). The parameters consisted of fourier transform infrared (FTIR) spectrometry, initial plasticity $(P o)$, plasticity retention index (PRI), Mooney viscosity, viscosity stability index (SVI), ash content, and volatile content. The results showed that the best treatment of maleic anhydride addition in modifying the properties and characteristics of natural rubber polymers was a dose of $10 \% \mathrm{w} / \mathrm{w}$ dry rubber. From FTIR spectrometry analysis, the maleic anhydride groups in natural rubber had been seen in this dose. The technical quality of natural rubber that has been modified using maleic anhydride $10 \% \mathrm{w} / \mathrm{w}$ dry rubber, namely Po 27, PRI 54.95, Mooney viscosity 78 , SVI 4, ash content $0.51 \%$ and volatile content $0.26 \%$.
\end{abstract}

Keywords: Maleic anhydride; modification; natural rubber; quality

\section{Abstrak}

Pemaduan (blending) polimer karet alam dengan pati alam yang mempunyai sifat dan karakteristik berbeda dapat menghasilkan polimer dengan karakteristik baru. Polimer karet alam yang non polar perlu dimodifikasi agar dapat berinteraksi secara baik dengan pati alam yang bersifat polar. Penggunaan aditif anhidrida maleat dapat meningkatkan interaksi dengan pati alam. Penelitian ini bertujuan untuk mempelajari dan memperoleh dosis terbaik penggunaan aditif anhidrida maleat dalam memodifikasi sifat polimer karet alam. Dengan dosis ini diharapkan dapat menghasilkan karet alam termodifikasi dengan karakteristik dan mutu teknis yang berbeda sehingga dapat dipadukan dengan pati alam. Perlakuan berupa penambahan anhidrida maleat dengan dosis $5 \%$ berat per berat (b/b) karet kering, 10\% b/b, 15\% b/b dan kontrol (karet tanpa anhidrida maleat). Parameter pengamatan terdiri dari analisa spektrometri fourier transform infrared (FTIR), plastisitas awal (Po), indeks ketahanan plastisitas (PRI), viskositas Mooney, indeks kestabilan viskositas (SVI), kadar abu, dan kadar zat menguap. Hasil penelitian menunjukkan bahwa perlakuan penambahan aditif anhidrida maleat terbaik dalam memodifikasi sifat dan karakteristik polimer karet alam adalah dosis $10 \% \mathrm{~b} / \mathrm{b}$ karet kering. Dari analisa spektrometri FTIR, gugus anhidrida maleat dalam karet alam sudah terlihat pada dosis ini. Mutu teknis karet alam yang sudah dimodifikasi menggunakan maleat anhidrida $10 \% \mathrm{~b} / \mathrm{b}$ karet kering, yaitu Po 27; PRI 54,95; viskositas Mooney 78; SVI 4; kadar abu $0,51 \%$ dan kadar zat menguap $0,26 \%$. 
Kata kunci: Karet alam; maleat anhidrida; modifikasi; mutu

\section{PENDAHULUAN}

Karet alam merupakan salah satu komoditi penting bagi Indonesia. Produksi karet alam Indonesia mencapai 3,2 juta ton pada tahun 2017 (Direktorat Jenderal Perkebunan (Ditjenbun), 2016) dimana lebih dari 90\% diekspor dalam bentuk karet mentah (karet remah dan sit asap/RSS) (Gabungan Perusahaan Karet Indonesia (Gapkindo), 2018) ke berbagai negara tujuan. Diversifikasi produk karet alam perlu dilakukan untuk mengurangi ketergantungan terhadap produksi ban. Salah satu bentuk diversifikasi yang dapat dilakukan adalah dengan menggabungkan karet alam dengan berbagai polimer alam lainnya yang mempunyai sifat dan karakteristik yang berbeda. Penggabungan dua polimer dengan sifat dan karakteristik berbeda tersebut diharapkan dapat menghasilkan polimer atau komposit dengan karakteristik baru.

Pati alam merupakan polimer alam yang paling banyak dan mudah diperoleh. Dengan menggabungkan polimer karet alam dengan pati alam, selain mendapatkan polimer dengan karakteristik yang baru, juga mendukung upaya menghasilkan produk baru yang ramah lingkungan. Marlina dan Prasetya (2017), Ichazo et al. (2011), Pulungan et al. (2017) serta Cifriadi (2013) sudah melakukan penelitian mengenai pembuatan komposit dari penggabungan pati alam dengan karet alam. Kedua polimer tersebut, pati alam dan karet alam, mempunyai sifat yang berbeda. Polimer karet alam yang berupa poliisoprena mempunyai gugus fungsi yang bersifat non polar, sedangkan pati alam yang umumnya terdiri dari amilosa dan amilopektin mempunyai gugus fungsi yang bersifat polar. Untuk dapat menggabungkan kedua polimer karet alam tersebut, dapat dilakukan dengan merekayasa salah satu dari kedua polimer sehingga dapat meningkatkan interaksi kedua polimer tersebut.

Polimer karet alam yang bersifat non polar perlu direkayasa agar mempunyai gugus fungsi bersifat polar. Dengan perubahan sifat kepolaran tersebut, polimer karet alam dapat diikatkan dengan pati alam. Untuk merubah sifat dan meningkatkan interaksi karet alam dengan pati diperlukan bahan aditif sebagai penghubung (coupling agent). Salah satu bahan aditif tersebut adalah anhidrida maleat. Karet alam yang telah dimodifikasi dengan anhidrida maleat ke struktur polimer karet alam disebut dengan maleated natural rubber (MNR). Penggunaan anhidrida maleat sebagai coupling agent terus dikembangkan karena penambahan bahan aditif ini akan meningkatkan adsorpsi air pada karet alam dikarenakan sifatnya yang menjadi hidrofilik (Putra et al., 2014).

Penelitian mengenai penggunaan anhidrida maleat sebagai coupling agent karet alam dengan beberapa polimer lain sudah banyak dilakukan (Putra et al., 2014; Daulay, 2005; Ichazo et al., 2011; dan Onyeagoro, 2013). Tetapi penelitian yang menyajikan karakteristik dan mutu teknis karet alam mentah yang sudah termodifikasi menggunakan anhidrida maleat sebelum pencampuran (blending) dengan polimer lain masih belum banyak dilakukan. Penelitian ini memberikan gambaran karakteristik dan mutu teknis karet alam mentah yang sudah termodifikasi dengan anhidrida maleat kaitannya dengan pengaruh dosis penambahan bahan aditif anhidrida maleat.

Penambahan bahan aditif ke dalam karet alam dapat mempengaruhi sifat dan mutu teknis karet mentah yang akan dihasilkan (Cifriadi, 2013). Penelitian ini bertujuan untuk mempelajari dan memperoleh dosis terbaik penggunaan aditif anhidrida maleat dalam memodifikasi sifat polimer karet alam. Dosis ini diharapkan dapat menghasilkan karet alam termodifikasi yang mempunyai karakteristik dan mutu teknis yang tidak berbeda dengan karet alam tanpa dimodifikasi.

\section{BAHAN DAN METODE}

\section{Bahan dan Peralatan}

Penelitian ini dilakukan di Laboratorium Teknologi Pengolahan Balai Penelitian Sembawa-Pusat Penelitian Karet. Bahan yang digunakan berupa blanket karet alam dari kebun riset Balai Penelitian 
Sembawa, anhidrida maleat produksi Sigma Aldrich, $\mathrm{P}_{2} \mathrm{O}_{5}$ dari Merck, toluena dari Merck dan aseton teknis. Peralatan yang digunakan antara lain mesin creeper, gilingan terbuka (open mill), oven, rapid plastimeter, Mooney viskometer, neraca digital, stopwatch, dan muffle furnace.

\section{Metodologi}

Perlakuan yang diberikan berupa penambahan anhidrida maleat dengan dosis $5 \%$ berat per berat $(\mathrm{b} / \mathrm{b})$ karet kering, 10\% $\mathrm{b} / \mathrm{b}, 15 \% \mathrm{~b} / \mathrm{b}$ dan kontrol (karet tanpa anhidrida maleat). Untuk menentukan ikatan yang terbentuk oleh anhidrida maleat pada karet alam secara kualitatif akan dilakukan analisis spektometri fourier transform infrared (FTIR). Parameter mutu teknis yang diamati terdiri atas plastisitas awal (Po), indeks ketahanan plastisitas (plasticity retention index/PRI), viskositas Mooney, indeks kestabilan viskositas (stability viscosity index/SVI), kadar abu, dan kadar zat menguap. Parameter mutu teknis dilakukan untuk melihat perubahan karet alam sebelum dan sesudah dimodifikasi menggunakan bahan aditif anhidrida maleat. Parameter mutu ini sesuai persyaratan Standar Nasional Indonesia (SNI) 06-1903-2000 tentang Standard Indonesia Rubber (SIR). Karet alam Indonesia yang akan diekspor ke berbagai negara tujuan harus memenuhi SNI 061903-2000.

\section{Penyiapan Blanket Karet Alam}

Bahan baku yang digunakan untuk pembuatan blanket karet alam adalah koagulum (lateks yang sudah menggumpal secara alami) dari kebun riset Balai Penelitian Sembawa. Koagulum tersebut selanjutnya digiling menggunakan mesin creeper menjadi blanket. Blanket tersebut dikeringkan dalam oven bersuhu $\pm 110{ }^{\circ} \mathrm{C}$ selama sekitar 3-4 jam hingga kering.

\section{Prosedur Pembuatan Karet Alam Termodifikasi Menggunakan Anhidrida Maleat}

Karet alam termodifikasi dibuat dengan cara menambahkan anhidrida maleat pada karet alam menggunakan mesin gilingan terbuka (open mill). Dosis penambahan aditif disesuaikan dengan perlakuan. Sebelum dilakukan proses penambahan, karet alam terlebih dahulu melewati proses mastikasi. Tujuannya untuk memutus rantai polimer karet alam menjadi lebih pendek sehingga proses penambahan aditif anhidrida maleat menjadi lebih maksimal. Proses mastikasi diawali dengan pemanasan rol gilingan pada mesin open mill sampai suhu $\pm 75^{\circ} \mathrm{C}$ selama sekitar 1 jam. Proses penambahan anhidrida maleat pada blanket (fasa padat) ini dilakukan pada suhu tersebut. Setelah gilingan panas, karet dimastikasi dan anhidrida malaet yang telah ditimbang dicampurkan. Selama proses penggilingan, lembaran karet dipotong secara bergantian bagian kiri/kanan hingga bahan-bahan tercampur dengan baik dan karet menjadi plastis.

\section{Analisa FTIR dan Mutu Teknis}

Karet alam yang dimodifikasi menggunakan anhidrida maleat selanjutnya akan akan dianalisis spektrometri inframerah (FTIR) dan mutu teknis. Analisa mutu teknis dilakukan sesuai dengan prosedur analisa karet alam mentah seperti tercantum pada SNI 06-1903-2000.

\section{HASIL DAN PEMBAHASAN}

\section{Modifikasi Struktur Polimer Karet Alam Menggunakan Anhidrida Maleat}

Hasil analisis spektometri inframerah karet alam kontrol (tanpa penambahan anhidrida maleat) disajikan pada Gambar 1. Sementara hasil analisa karet alam dengan penambahan anhidrida maleat $5 \% \mathrm{~b} / \mathrm{b}, 10 \% \mathrm{~b} / \mathrm{b}$, dan $15 \% \mathrm{~b} / \mathrm{b}$ dapat dilihat pada Gambar 2, Gambar 3, dan Gambar 4 berturut-turut. Tafsiran gugus fungsional dari hasil analisis inframerah dapat dilihat pada Tabel 1.

Berdasarkan Gambar 1 sampai Gambar 4 diketahui bahwa penambahan anhidrida maleat dengan dosis $10 \% \mathrm{~b} / \mathrm{b}$ dan $15 \% \mathrm{~b} / \mathrm{b}$ secara kualitatif dapat merubah (memodifikasi) struktur polimer karet alam. Efek penambahan anhidrida maleat pada karet alam dapat dilihat dengan hilangnya puncak serapan inframerah pada panjang gelombang $2726 \mathrm{~cm}^{-1}$ dan digantikan dengan munculnya puncak serapan inframerah pada panjang gelombang $1704 \mathrm{~cm}^{-1}$ dimana 
puncak serapan ini merupakan puncak serapan gugus anhidrida $(\mathrm{C}=\mathrm{O}$ stretching) yang ditambahkan pada karet alam. Puncak serapan inframerah ini serupa dengan puncak serapan maleated natural rubber yang telah dianalisa oleh Wati et al. (2012).
Puncak serapan ini belum dijumpai pada karet alam yang hanya ditambahkan dengan anhidrida maleat $5 \% \mathrm{~b} / \mathrm{b}$. Dengan dosis yang rendah tersebut (dosis $5 \% \mathrm{~b} / \mathrm{b}$ ), maleat anhidrida diduga belum mampu terikat pada struktur poliisoprena.

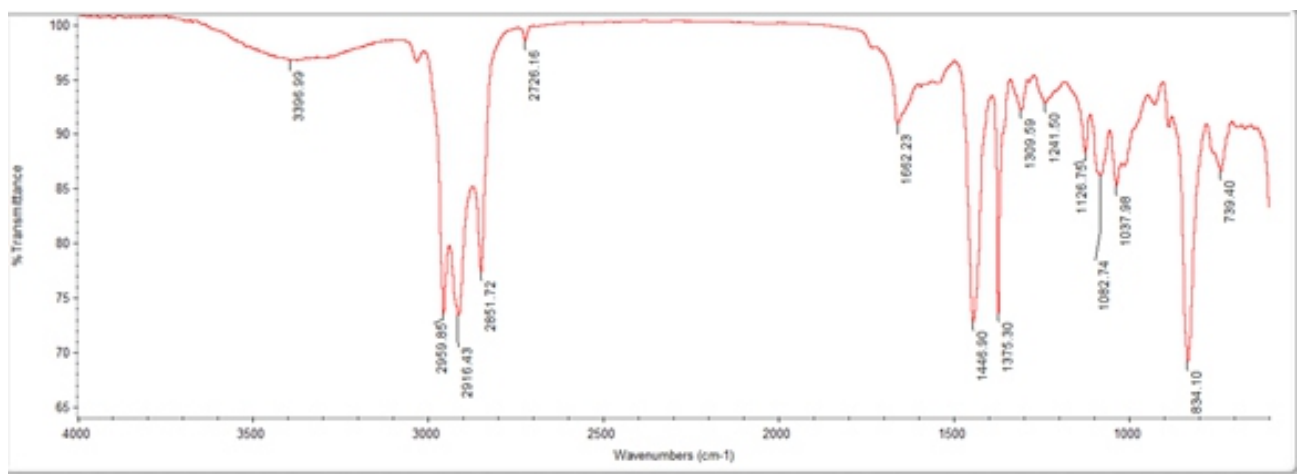

Gambar 1. Spektrum infra merah dari sampel karet alam tanpa anhidrida maleat $(0 \%$ atau kontrol)

Figure 1. Infrared spectrum of natural rubber sample without maleic anhydride (0\% or control)

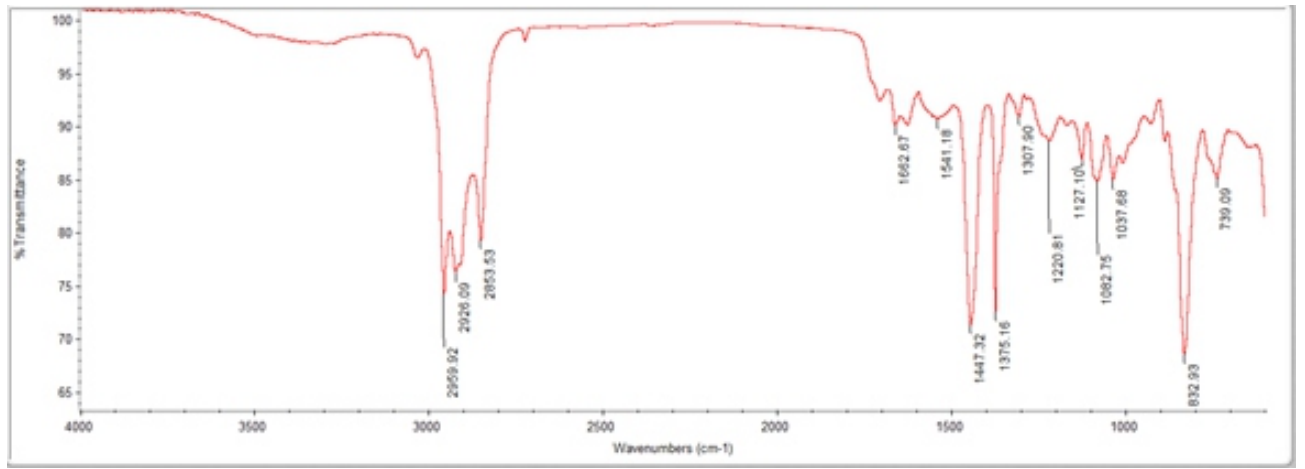

Gambar 2. Spektrum infra merah dari sampel karet alam dengan penambahan anhidrida maleat sekitar $5 \%$ b/b

Figure 2. Infrared spectrum of natural rubber sample with the addition of maleic anhydride of about $5 \% w / w$

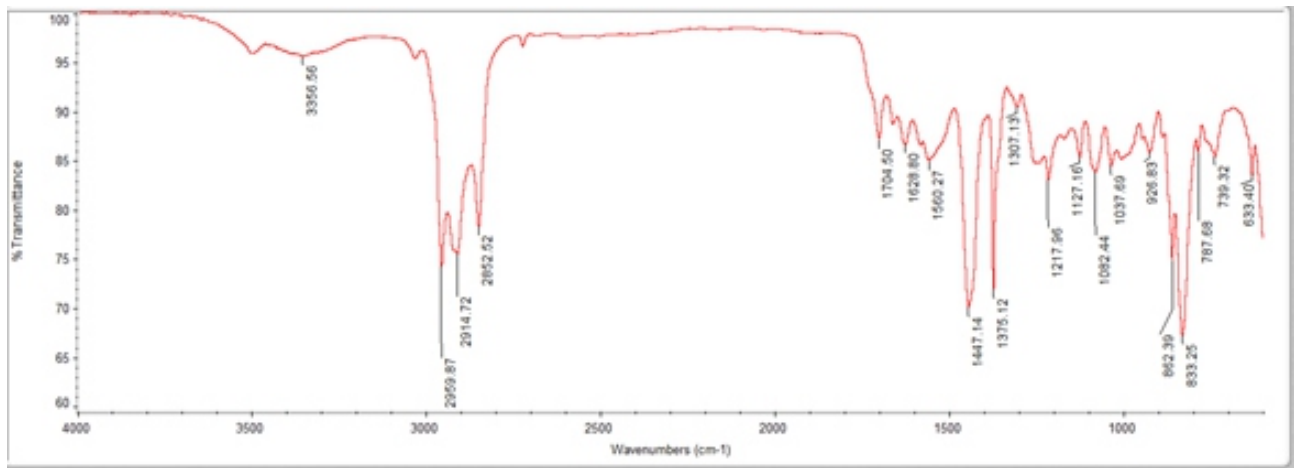

Gambar 3. Spektrum infra merah dari sampel karet alam dengan penambahan anhidrida maleat sekitar $10 \% \mathrm{~b} / \mathrm{b}$

Figure 3. Infrared spectrum of natural rubber sample with the addition of maleic anhydride of about 10\% w/w 


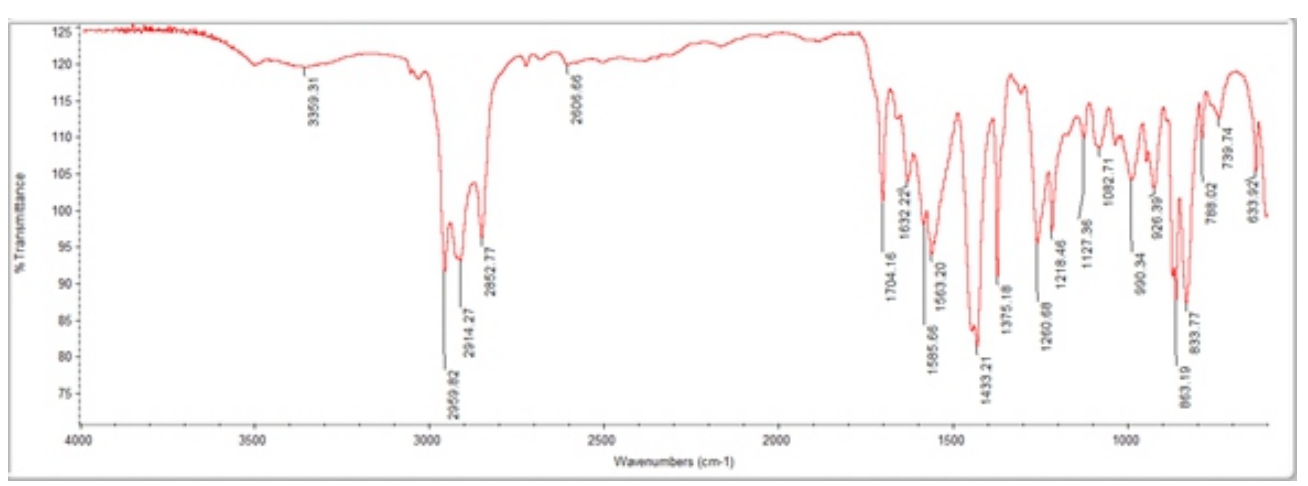

Gambar 4. Spektrum infra merah dari sampel karet alam dengan penambahan anhidrida maleat sekitar $15 \% \mathrm{~b} / \mathrm{b}$

Figure 4. Infrared spectrum of natural rubber sample with the addition of maleic anhydride of about $15 \% w / w$

Tabel 1. Analisis spektrum inframerah

Table 1. Infrared spectrum analysis

\begin{tabular}{|c|c|c|c|c|c|c|c|}
\hline \multicolumn{2}{|c|}{$\begin{array}{c}\text { Karet alam } \\
\text { Natural rubber }\end{array}$} & \multicolumn{2}{|c|}{$\begin{array}{l}\text { Karet alam dan Anhidrida } \\
\text { maleat } 5 \% \mathrm{~b} / \mathrm{b} \\
\text { Natural rubber and Maleic } \\
\text { anhydride } 5 \% \mathrm{w} / \mathrm{w}\end{array}$} & \multicolumn{2}{|c|}{$\begin{array}{c}\text { Karet alam + Anhidrida } \\
\text { maleat } 10 \% \mathrm{~b} / \mathrm{b} \\
\text { Natural rubber and Maleic } \\
\text { anhydride } 10 \% \mathrm{w} / \mathrm{w}\end{array}$} & \multicolumn{2}{|c|}{$\begin{array}{c}\text { Karet alam + Anhidrida } \\
\text { maleat } 15 \% \mathrm{~b} / \mathrm{b} \\
\text { Natural rubber and maleic } \\
\text { anhydride } 15 \% \mathrm{w} / \mathrm{w}\end{array}$} \\
\hline $\begin{array}{l}\text { Bilangan } \\
\text { gelombang } \\
\text { Wave } \\
\text { numbers } \\
\left(\mathrm{cm}^{-1}\right)\end{array}$ & $\begin{array}{c}\text { Tafsiran } \\
\text { Interpretation }\end{array}$ & $\begin{array}{l}\text { Bilangan } \\
\text { gelombang } \\
\text { Wave } \\
\text { numbers } \\
\left(\mathrm{cm}^{-1}\right)\end{array}$ & $\begin{array}{c}\text { Tafsiran } \\
\text { Interpretation }\end{array}$ & $\begin{array}{c}\text { Bilangan } \\
\text { gelombang } \\
\text { Wave numbers } \\
\left(\mathrm{cm}^{-1}\right)\end{array}$ & $\begin{array}{c}\text { Tafsiran } \\
\text { Interpretation }\end{array}$ & $\begin{array}{l}\text { Bilangan } \\
\text { gelombang } \\
\text { Wave } \\
\text { numbers } \\
\left(\mathrm{cm}^{-1}\right)\end{array}$ & $\begin{array}{c}\text { Tafsiran } \\
\text { Interpretation }\end{array}$ \\
\hline 2959 & $\begin{array}{l}\text { Vibrasi } \\
\text { regangan } \mathrm{CH} \\
\text { pada }-\mathrm{C}=\mathrm{C}- \\
\text { Vibrasi } \\
\text { sympathetic }\end{array}$ & 2959 & $\begin{array}{c}\text { Vibrasi } \\
\text { regangan } \mathrm{CH} \\
\text { pada }-\mathrm{C}=\mathrm{C}- \\
-\end{array}$ & 2959 & $\begin{array}{c}\text { Vibrasi } \\
\text { regangan } \mathrm{CH} \\
\text { pada }-\mathrm{C}=\mathrm{C}- \\
-\end{array}$ & 2959 & $\begin{array}{c}\text { Vibrasi } \\
\text { regangan } \mathrm{CH} \\
\text { pada }-\mathrm{C}=\mathrm{C}- \\
-\end{array}$ \\
\hline- & - & - & - & 1704 & $\begin{array}{l}\text { Vibrasi } \\
\text { regangan } \\
\mathrm{C}=\mathrm{O}\end{array}$ & 1704 & $\begin{array}{l}\text { Vibrasi } \\
\text { regangan } \\
\mathrm{C}=\mathrm{O}\end{array}$ \\
\hline 1662 & $\begin{array}{l}\text { Vibrasi } \\
\text { regangan } \mathrm{C}=\mathrm{C}\end{array}$ & 1662 & $\begin{array}{l}\text { Vibrasi } \\
\text { regangan } \\
\mathrm{C}=\mathrm{C}\end{array}$ & 1628 & $\begin{array}{l}\text { Vibrasi } \\
\text { regangan } \\
\mathrm{C}=\mathrm{C}\end{array}$ & 1632 & $\begin{array}{l}\text { Vibrasi } \\
\text { regangan } \\
\mathrm{C}=\mathrm{C}\end{array}$ \\
\hline 1375 & $\begin{array}{c}\text { Vibrasi } \\
\text { scissoring } \mathrm{CH}_{3}\end{array}$ & 1375 & $\begin{array}{c}\text { Vibrasi } \\
\text { scissoring } \\
\mathrm{CH}_{3}\end{array}$ & 1375 & $\begin{array}{c}\text { Vibrasi } \\
\text { scissoring } \\
\mathrm{CH}_{3}\end{array}$ & 1375 & $\begin{array}{l}\text { Vibrasi } \\
\text { scissoring } \\
\mathrm{CH}_{3}\end{array}$ \\
\hline 1309 & $\begin{array}{c}\text { Vibrasi } \\
\text { scissoring } \mathrm{CH}_{3} \\
\text { atau } \mathrm{CH}\end{array}$ & 1307 & $\begin{array}{c}\text { Vibrasi } \\
\text { scissoring } \\
\mathrm{CH}_{3} \text { atau } \mathrm{CH}\end{array}$ & 1307 & $\begin{array}{c}\text { Vibrasi } \\
\text { scissoring } \\
\mathrm{CH}_{3} \text { atau } \mathrm{CH}\end{array}$ & 1260 & $\begin{array}{c}\text { Vibrasi } \\
\text { scissoring } \\
\mathrm{CH}_{3} \text { atau } \mathrm{CH}\end{array}$ \\
\hline 1126 & $\begin{array}{c}\text { Vibrasi } \\
\text { regangan CC } \\
\text { pada rantai } \\
\text { utama }\end{array}$ & 1127 & $\begin{array}{c}\text { Vibrasi } \\
\text { regangan CC } \\
\text { pada rantai } \\
\text { utama }\end{array}$ & 1127 & $\begin{array}{c}\text { Vibrasi } \\
\text { regangan CC } \\
\text { pada rantai } \\
\text { utama }\end{array}$ & 1127 & $\begin{array}{c}\text { Vibrasi } \\
\text { regangan CC } \\
\text { pada rantai } \\
\text { utama }\end{array}$ \\
\hline 1037 & $\begin{array}{c}\text { Vibrasi } \\
\text { regangan atau } \\
\text { waggingpada } \\
\mathrm{CH}_{3} \mathrm{C}=\mathrm{C}\end{array}$ & 1037 & $\begin{array}{l}\text { Vibrasi } \\
\text { regangan } \\
\text { atau } \\
\text { wagging } \\
\text { pada } \\
\mathrm{CH}_{3} \mathrm{C}=\mathrm{C}\end{array}$ & 1037 & $\begin{array}{c}\text { Vibrasi } \\
\text { regangan } \\
\text { atau wagging } \\
\text { pada } \\
\mathrm{CH}_{3} \mathrm{C}=\mathrm{C}\end{array}$ & 990 & $\begin{array}{c}\text { Vibrasi } \\
\text { regangan } \\
\text { atau wagging } \\
\text { pada } \mathrm{CH}_{3} \mathrm{C}=\mathrm{C}\end{array}$ \\
\hline 834 & $\begin{array}{c}\text { Vibrasi } \\
\text { bending out-of- } \\
\text { plane } \mathrm{C}-\mathrm{H} \\
\text { pada } \mathrm{CH}=\mathrm{CH}- \\
\text { group }\end{array}$ & 832 & $\begin{array}{c}\text { Vibrasi } \\
\text { bending out- } \\
\text { of-plane } \mathrm{C}-\mathrm{H} \\
\text { pada } \\
\mathrm{CH}=\mathrm{CH}- \\
\text { group }\end{array}$ & 833 & $\begin{array}{c}\text { Vibrasi } \\
\text { bending out- } \\
\text { of-plane } \mathrm{C}-\mathrm{H} \\
\text { pada } \\
\mathrm{CH}=\mathrm{CH}- \\
\text { group }\end{array}$ & 833 & $\begin{array}{c}\text { Vibrasi } \\
\text { bending out- } \\
\text { of-plane } \mathrm{C}-\mathrm{H} \\
\text { pada } \mathrm{CH}=\mathrm{CH}- \\
\text { group }\end{array}$ \\
\hline
\end{tabular}


Hal ini juga dapat dilihat dari tafsiran puncak-puncak serapan inframerah berdasarkan karakteristik serapan gugus fungsional yang umum diketahui (Tabel 1). Hasil tafsiran puncak-puncak serapan inframerah pada karet alam termodifikasi ini juga sesuai dengan beberapa penelitian yang sudah pernah dilakukan (Socrates, 1994; Nakason et al., 2006; Wati et al., 2012; Chen et al., 2013). Karet alam dari pohon Hevea Brasiliensis memiliki lebih dari 5000 gugus fungsi cis-1,4 poliisoprena (Chen, 2013). Penambahan anhidrida maleat akan memodifikasi struktur poliisoprena menjadi maleated natural rubber. Mekanisme reaksi anhidrida maleat pada struktur poliisoprena terlihat seperti pada Gambar 5. Anhidrida maleat yang ditambahkan akan tercangkok pada monomer isoprena. Reaksi seperti inilah yang sudah terjadi pada karet alam termodifikasi menggunakan anhidrida maleat mulai dari $10 \% \mathrm{~b} / \mathrm{b}$. Pada dosis ini struktur poliisoprena (karet alam) telah mengalami perubahan dengan adanya gugus baru maleat anhidrida.

\section{Plastisitas Karet Alam Termodifikasi}

Parameter mutu plastisitas karet alam yang dianalisa terdiri dari plastisitas awal (Po) dan indeks ketahanan plastisitas (plasticity retention index/PRI). Hasil analisis parameter mutu Po dan PRI disajikan pada Gambar 6 dan 7. Nilai Po dan PRI merupakan parameter dasar untuk menentukan mutu karet lembaran (Achmadi et al., 2015). Semakin tinggi nilai PRI, maka semakin baik mutu karet (Montha et al., 2016).

Penggunaan anhidrida maleat pada karet alam dapat berpengaruh terhadap nilai plastisitas awal (Po) dari karet alam. Penambahan anhidrida maleat pada fase padat akan meningkatkan nilai Po karet<smiles>CCCCCCCC</smiles>

Cis 1,4 poliisoprene

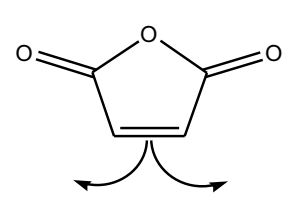

Maleat anhidrida

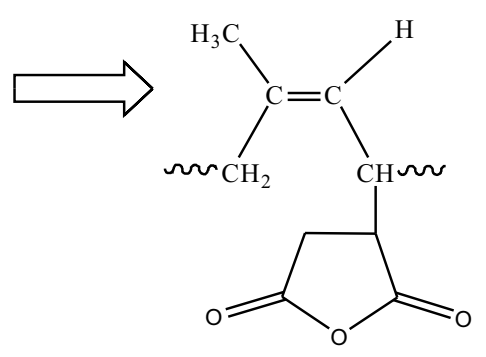

Maleat-cis 1,4 poliisoprene

Gambar 5. Mekanisme reaksi yang mungkin terjadi pada reaksi karet alam dan maleat anhidrida (Nakason et al., 2006)

Figure 5. Mechanism of reactions that may occur in the reaction of natural rubber and maleic anhydride (Nakason et al., 2006)

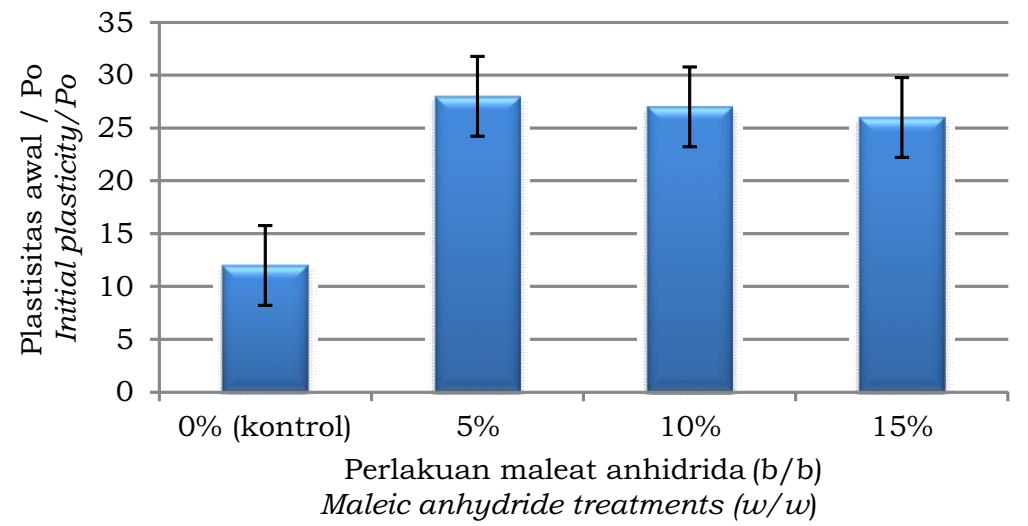

Gambar 6. Plastisitas awal (Po) karet alam termodifikasi dengan berbagai perlakuan penambahan maleat anhidrida

Figure 6. Initial plasticity (Po) of modified natural rubber with various treatments of the addition of maleic anhydride 


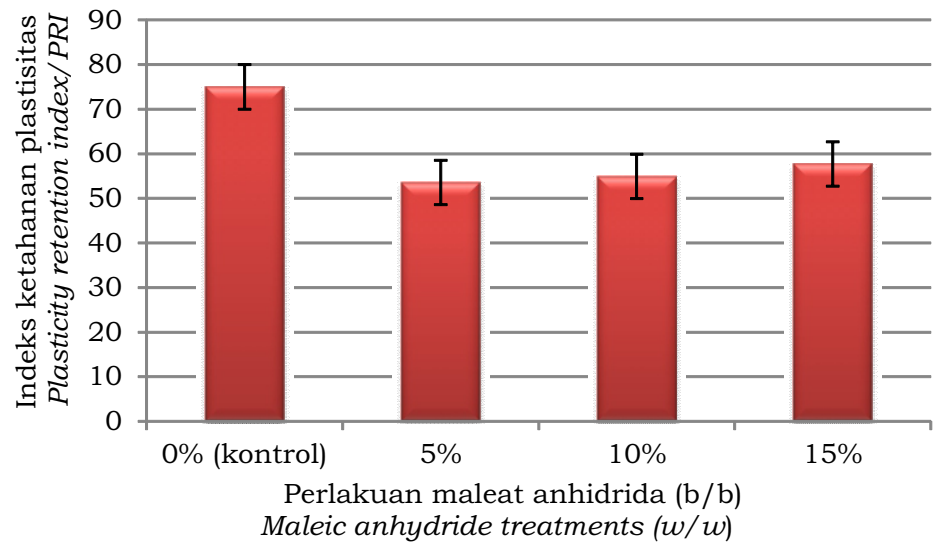

Gambar 7. Indeks ketahanan plastisitas (PRI) karet alam termodifikasi dengan berbagai perlakuan penambahan anhidrida maleat

Figure 7. Plasticity retention index (PRI) of modified natural rubber with various treatments of the addition of maleic anhydride

alam (Gambar 6) dimana nilai Po karet alam kontrol (tanpa penambahan bahan aditif) hanya 12 , sedangkan karet alam yang dimodifikasi dengan anhidrida maleat mempunyai nilai Po sekitar 26-28. Nilai Po adalah ukuran plastisitas karet yang secara tidak langsung memperkirakan panjangnya rantai molekul polimer atau berat molekul (BM) karet.

Hasil analisis nilai Po ini memberikan gambaran bahwa polimer karet alam yang dimodifikasi dengan aditif anhidrida maleat mempunyai rantai molekul yang lebih panjang dibandingkan karet alam kontrol. Selama proses mastikasi dengan pemanasan, rantai polimer karet alam mengalami pemutusan dan membentuk radikal bebas. Pulungan et al. (2017) menyatakan bahwa radikal bebas merupakan satu atau lebih elektron yang tidak berpasangan adalah pemicu terjadinya pencangkokan kopolimerisasi. Bahan aditif anhidrida maleat yang ditambahkan akan bereaksi (tercangkok) dengan gugus poliisoprena membentuk gugus fungsi baru (Gambar $5)$.

Parameter mutu indeks ketahanan plastisitas (PRI) adalah suatu ukuran ketahanan karet terhadap pengusangan (oksidasi) pada suhu tinggi. Nilai PRI diukur dari besarnya keliatan karet mentah yang masih tertinggal apabila sampel tersebut dipanaskan selama 30 menit pada suhu 140 ${ }^{\circ} \mathrm{C}$. Nilai PRI merupakan persentase keliatan karet sesudah dipanaskan dibandingkan dengan keliatan sebelum dipanaskan dan ditentukan dengan alat Wallace Plastimeter. Nilai Po dan PRI merupakan parameter dasar untuk menentukan mutu karet (Achmadi et al., 2015).

Seperti terlihat pada Gambar 7 diketahui bahwa penggunaan aditif anhidrida maleat pada karet alam dapat menurunkan nilai PRI. Karet alam tanpa penambahan aditif (kontrol) mempunyai nilai PRI 75, sedangkan karet alam yang sudah dimodifikasi menggunakan anhidrida maleat mempunyai nilai PRI berkisar 53,5757,69. Angka ini menunjukkan bahwa karet alam yang sudah dimodifikasi dengan anhidrida maleat tidak tahan terhadap proses oksidasi pada suhu tinggi. Rendahnya ketahanan karet alam termodifikasi terjadi karena adanya gugus fungsi baru yang tidak tahan terhadap oksidasi.

\section{Viskositas dan Kestabilannya}

Parameter mutu viskositas yang diamati pada penelitian ini berupa viskositas Mooney dan indeks kestabilan viskositas (stability viscosity index/SVI). Parameter mutu viskositas Mooney biasanya digunakan juga sebagai indikator teknologi untuk mengetahui karakterisasi partikel karet ditinjau dari kemampuannya saat pemrosesan lebih lanjut, termasuk pada saat pembuatan kompon (Zheleva, 2013). Berbeda dengan viskositas, parameter SVI lebih menggambarkan perubahan nilai viskositas Mooney karet alam selama penyimpanan sebelum karet alam diproses 
lebih lanjut menjadi barang jadi karet. Nilai SVI ini menunjukkan seberapa stabil viskositas karet alam selama penyimpanan. Hasil analisis viskositas Mooney dan SVI karet berbagai perlakuan dapat dilihat pada Gambar 8 dan Gambar 9.

Berdasarkan Gambar 8 diketahui bahwa karet alam yang rantai polimernya sudah dimodifikasi menggunakan aditif anhidrida maleat mempunyai nilai viskositas Mooney lebih tinggi dibandingkan kontrol. Nilai viskositas Mooney yang tinggi ini mencerminkan telah banyak rantai molekul karet alam yang telah mengalami percabangan dan membentuk jaringan tiga dimensi (Suparto et al., 2009). Nilai viskositas Mooney karet alam termodifikasi berkisar 66-78 yang berbeda dengan karet alam kontrol hanya 34. Hasil analisa ini menunjukkan bahwa karet alam yang sudah termodifikasi memiliki rantai polimer lebih panjang dibandingkan kontrol.

Nilai viskositas Mooney karet alam termodifikasi mengalami peningkatan sampai perlakuan anhidrida maleat dosis $10 \% \mathrm{~b} / \mathrm{b}$, yaitu sebesar 78 . Tetapi pada perlakuan penambahan anhidrida maleat dengan dosis $15 \% \mathrm{~b} / \mathrm{b}$ viskositas Mooney karet alam termodifikasi mengalami penurunan menjadi 72 . Hal ini disebabkan pada dosis anhidrida maleat $10 \% \mathrm{~b} / \mathrm{b}$ ikatan silang (cross linking) yang terjadi pada polimer karet alam lebih optimal sehingga menjadikan rantai polimer yang terbentuk lebih panjang, baik ikatan antar partikel alam maupun ikatan yang terbentuk dari reaksi penambahan anhidrida maleat.
Perbedaan penambahan kadar/dosis anhidrida maleat yang dicangkokkan pada struktur karet alam menyebabkan perbedaan berat molekul karet alam pengaruh dari rantai cabang yang terbentuk (Wati et al., 2012). Parameter viskositas Mooney menggambarkan panjang rantai molekul karet alam. Semakin tinggi nilai viskositas Mooney karet alam, maka semakin panjang rantai molekulnya.

Dari hasil analisis viskositas Mooney ini terlihat bahwa rantai molekul polimer paling panjang terdapat pada perlakuan penambahan anhidrida maleat $10 \% \mathrm{~b} / \mathrm{b}$. Parameter mutu viskositas Mooney memegang peranan penting dalam proses pencampuran ketika pembuatan kompon, baik untuk tingkat dispersi bahan-bahan kimia kompon di dalam karet maupun energi yang diperlukan untuk penggilingan di mesin pencampur. Viskositas yang terlalu tinggi menyebabkan tingginya konsumsi daya mesin pemroses. Sebaliknya jika viskositasnya sangat rendah, menyebabkan rendahnya gaya geser pada pencampuran yang berakibat material cenderung beraglomerasi maka homogenitasnya rendah (Maspanger, 2008).

Viskositas karet alam secara alami akan mengalami pengerasan selama proses penyimpanan dan pengangkutan. Pengerasan ini ditandai dengan meningkatnya nilai viskositas Mooney karet alam. Karet alam dengan nilai indeks kestabilan viskositas (SVI) rendah menunjukkan lebih stabil dalam proses penyimpanan. Dari hasil analisis parameter

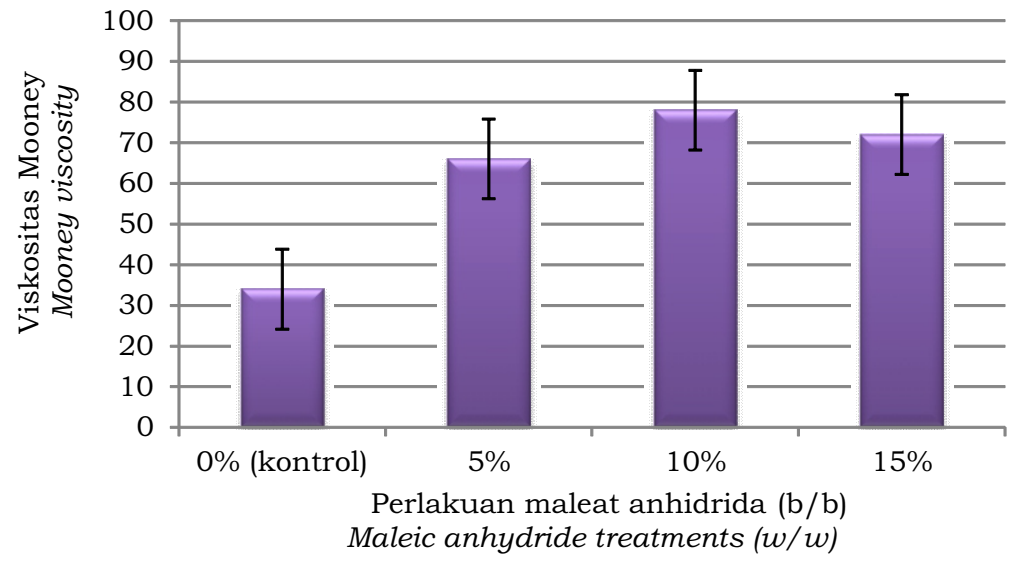

Gambar 8. Nilai viskositas karet alam termodifikasi menggunakan maleat anhidrida Figure 8 . The viscosity value of modified natural rubber using maleic anhydride 


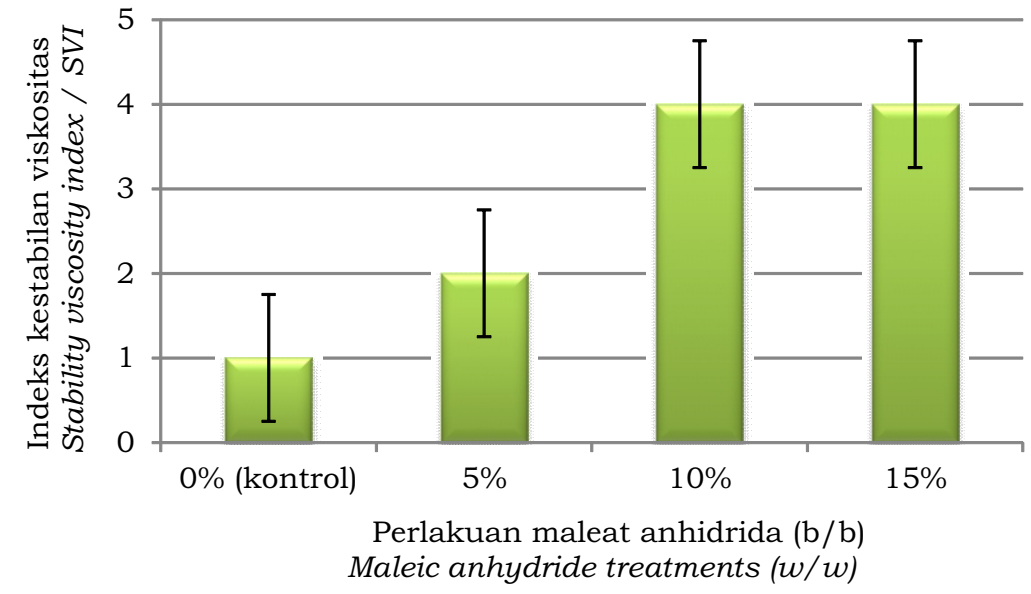

Gambar 9. Indeks kestabilan viskositas karet alam termodifikasi pada berbagai dosis anhidrida maleat

Figure 9. Stability viscosity index of modified natural rubber at various doses of maleic anhydride

SVI diketahui bahwa karet alam yang sudah dimodifikasi menggunakan anhidrida maleat lebih tidak stabil dibandingkan karet alam kontrol. Nilai SVI karet alam yang sudah dimodifikasi dengan anhidrida maleat yaitu sekitar 2-4. Angka ini lebih tinggi dibandingkan karet kontrol yang hanya 1 . Kondisi ini terjadi dikarenakan adanya gugus fungsi polar yang lebih mudah mengikat air sehingga dapat membuat viskositas karet menjadi kurang stabil. Berbeda dengan karet alam kontrol yang belum dimodifikasi, gugus fungsinya masih bersifat non polar. Ketidakstabilan karet alam kontrol lebih karena terjadinya ikatan silang antara partikel karet alam.

\section{Kadar Abu}

Hasil analisa kadar abu karet alam dengan berbagai perlakuan ditampilkan pada Gambar 10. Penggunaan aditif anhidrida maleat tidak berpengaruh terhadap kadar abu karet alam yang dihasilkan. Kadar abu karet alam termodifikasi sekitar 0,51-0,72\%, sedangkan karet alam kontrol kadar abunya sebesar 0,60\%. Kadar abu yang terlalu tinggi dalam karet alam mentah akan mempengaruhi sifat dinamika seperti kalor timbul (heat build up) dan ketahanan retak lentur (flex cracking resistance) (Departemen Perdagangan dan Koperasi, 1981).

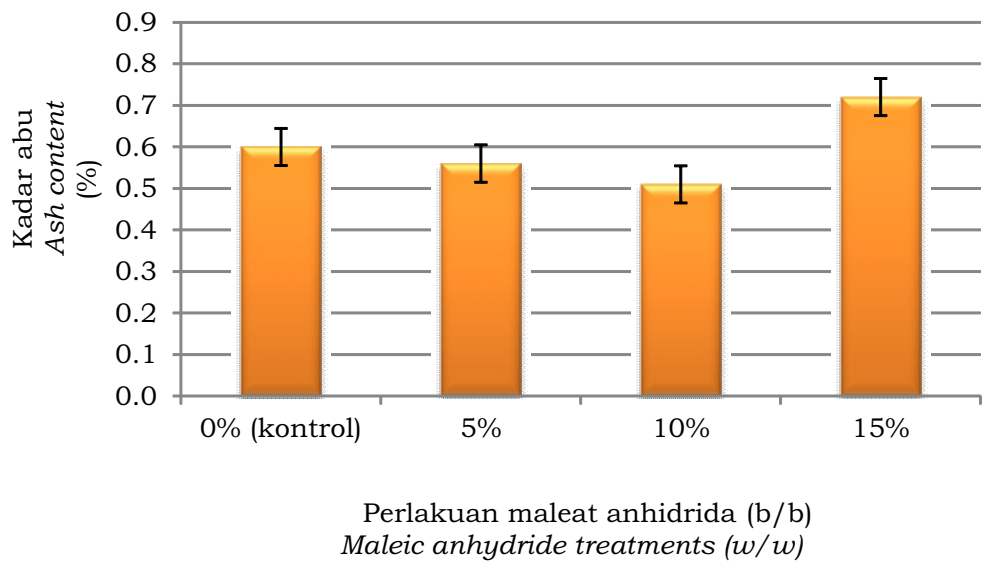

Gambar 10. Kadar abu karet alam termodifikasi menggunakan anhidrida maleat Figure 10. Ash content of modified natural rubber using maleic anhydride 
Kadar abu terendah diperoleh pada perlakuan penambahan anhidrida maleat $10 \% \mathrm{~b} / \mathrm{b}$, yaitu sebesar 0,51\%. Sementara itu kadar abu tertinggi dihasilkan karet alam termodifikasi dengan penambahan anhidrida maleat $15 \% \mathrm{~b} / \mathrm{b}$, yaitu sebesar $0,72 \%$. Perbedaan ini terjadi diduga terkait dengan proses pencangkokan anhidrida maleat. Pada dosis penambahan anhidrida maleat $10 \% \mathrm{~b} / \mathrm{b}$ proses pencangkokan terjadi lebih optimal sehingga aditif anhidrida maleat yang ditambahkan dapat tercangkok habis pada karet alam. Angka kadar abu sekitar 0,51\% pada karet alam termodifikasi tersebut berasal dari karet alam itu sendiri. George dan Jacob (2000) menyatakan bahwa total konsentrasi senyawa atau ion anorganik di dalam lateks segar adalah sekitar 0,50\%. Kondisi ini berbeda dengan perlakuan penambahan anhidrida maleat $15 \%$ b/b. Kadar abu karet alam termodifikasi yang dihasilkan mengalami peningkatan yaitu $0,72 \%$. Peningkatan ini diduga terjadi karena aditif anhidrida maleat yang ditambahkan tidak terikat semua dengan gugus poliisoprena (karet alam). Sebagian anhidrida maleat yang tidak terikat ini dapat teranalisis sebagai abu pada karet alam.

\section{Kadar Zat Menguap}

Zat menguap di dalam karet sebagian besar terdiri dari uap air dan sisanya adalah zat-zat lain seperti serum yang mudah menguap pada suhu $100{ }^{\circ} \mathrm{C}$. Adanya zat yang mudah menguap di dalam karet, selain dapat menyebabkan bau busuk, juga memudahkan tumbuhnya jamur yang dapat menimbulkan kesulitan pada waktu mencampurkan bahan-bahan kimia ke dalam karet pada waktu pembuatan kompon terutama untuk pencampuran karbon black pada suhu rendah (Badan Standardisasi Nasional, 2000). Hasil analisis kadar zat menguap dapat dilihat pada Gambar 11 .

Seperti terlihat pada Gambar 11 diketahui bahwa penggunaan aditif anhidrida maleat dapat menurunkan kadar zat menguap karet alam yang dihasilkan. Kadar zat menguap karet alam cenderung semakin rendah seiring dengan semakin tingginya dosis penambahan aditif anhidrida maleat. Karet alam yang sudah dimodifikasi dengan maleat anhidrida mempunyai kadar zat menguap sekitar 0,23-0,47\%. Angka ini masih lebih rendah dibandingkan karet alam kontrol (tanpa penambahan aditif) yang mempunyai kadar zat menguap

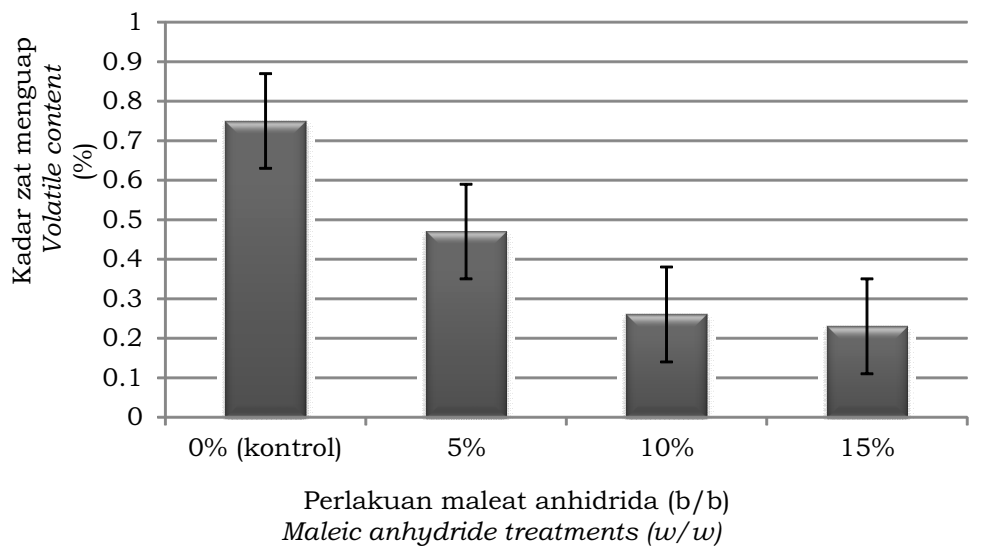

Gambar 11. Kadar zat menguap karet alam termodifikasi anhidrida maleat Figure 11. Volatile content of modified natural rubber using maleic anhydride

sebesar 0,75\%. Fenomena ini terjadi lebih disebabkan berubahnya gugus fungsi polimer karet alam dimana sebelumnya bersifat non polar, sekarang berubah menjadi polar yang lebih mudah mengikat air bahkan dapat larut dalam air.

\section{KESIMPULAN}

Perlakuan penambahan aditif anhidrida maleat terbaik dalam memodifikasi sifat dan karakteristik polimer karet alam adalah dosis $10 \% \mathrm{~b} / \mathrm{b}$ karet alam. Dari analisis spektometri fourier transform 
infrared (FTIR), pada dosis ini sudah terlihat adanya gugus anhidrida maleat di dalam polimer karet alam. Mutu teknis karet alam yang sudah dimodifikasi menggunakan anhidrida maleat $10 \% \mathrm{~b} / \mathrm{b}$, yaitu nilai Po 27 , PRI 54,95, viskositas 78, SVI 4, kadar abu 0,51\%, dan kadar zat menguap 0,26\%.

\section{UCAPAN TERIMA KASIH}

Pada kesempatan ini penulis ingin mengucapkan terima kasih kepada Kepala Balai Penelitian Sembawa yang telah memberikan izin dan mendukung pelaksanaan kegiatan penelitian ini melalui dana inhouse Balai Penelitian Sembawa.

\section{DAFTAR PUSTAKA}

Achmadi, S.S., Cifriadi, A., \& Hidayah, M.H. (2015). Redistilat asap cair dari cangkang kelapa sawit dan aplikasinya sebagai koagulan lateks. Jurnal Penelitian Karet, 33 (2), 183192. Doi: 10.22302/ppk.jpk.v33i2. 183.

Badan Standardisasi Nasional. (2000). Standard Indonesian Rubber, Standar Nasional Indonesia (SNI) No.06-19032011. ICS 83.060. Jakarta, Indonesia : BSN

Chen, D., Shao, H., Yao, W., \& Huang, B. (2013). Fourier transform infrared spectral analysis of polyisoprene of a different microstructure. International Journal of Polymer Science, 2013, 5p. Doi : $10.1155 / 2013 / 937284$.

Cifriadi, A. (2013). The effect of recorcinolformaldehyde (RF) loading as coupling agent on the physical properties and curing characteristics of starch/natural rubber composite. Proceeding The International Conference on the Innovation in Polymer and Technology (IPST) 2013 (pp. 4856). Yogyakarta, Indonesia : Himpunan Polimer Indonesia.

Daulay, L.R. (2005). Peranan anhidrida maleat terhadap kompatibilitas polietilena dan karet alam SIR 20 dengan pengisi pulp tandan kosong sawit. Jurnal Sains Kimia, 9(1), 16-20.
Departemen Perdagangan dan Koperasi. (1981). Metode Pengujian Standard Indonesian Rubber (SIR). Kursus Pengawasan Mutu SIR. Jakarta, Indonesia : Direktorat Standarisasi, Normalisasi dan Pengendalian Mutu.

Direktorat Jenderal Perkebunan. (2016). Statistik Perkebunan Indonesia 20152017 : Karet. Jakarta, Indonesia : Kementerian Pertanian, Ditjenbun.

Gapkindo. (2018). Ekspor karet Indonesia menurut jenis mutu 2010-2016. Jakarta, Indonesia : Gabungan Perusahaan Karet Indonesia (Gapkindo).

George, P.J., \& Jacob, C. (2000). Natural rubber : agromanagement and crop processing. India : Rubber Research Institute of India.

Ichazo, M.N., Albano, C., Hernández, M., González, J., \& Pena, J. (2011). Characterization of natural rubber/cassava starch/maleated natural rubber formulations. Revista Latinoamericana de Metalurgia $y$ Materiales, 31(1), 71-84.

Marlina, P., \& Prasetya, H.A. (2017). Karakteristik karet sheet dengan bahan baku komposit modifikasi patilateks. Jurnal Dinamika Penelitian Industri, 28(2), 112-119.

Maspanger, D.R. (2008). Sifat fisik karet. Makalah Kursus Teknologi Barang Jadi Karet. Bogor, Indonesia : Pusat Penelitian Karet.

Montha, S., Suwandittakul, P., Poonsrisawat, A., Oungeun, P., \& Kongkaew, C. (2016). Maillard reaction in natural rubber latex : characterization and physical properties of solid natural rubber. Advanced in Materials Science and Engineering, 2016, 1-6. Doi : $10.1155 / 2016 / 7807524$. 
Nakason, C., Saiwari, S., \& Kaesaman, A. (2006). Rheological, thermal and morphological properties of maleated natural rubber and its reactive blending with polymethyl methacrylate. Polymer Testing, 25(5), 656-667. Doi : 10.1016/j.polymer testing.2006.03.011.

Onyeagoro, G.N. (2013). Reactive compatibilization of natural rubber (NR)/carboxylated nitrile rubber (XNBR) blends by maleic anhydridegrafted polyisoprene (MAPI) and epoxy resin dual compatibilizers. International Refereed Journal of Engineering and Science (IRJES), 2(3), 7-16.

Pulungan, A.N., Wirjosentono, B., Eddiyanto., \& Hendrana, S. (2017). Grafting maleat anhidrida pada lateks karet alam dengan inisiator benzoil peroksida. Prosiding Seminar Hilirisasi Penelitian untuk Kesejahteraan Masyarakat. Medan, Indonesia: Lembaga Penelitian Universitas Negeri Medan.

Putra, A., Yelmida., \& Bahruddin. (2014). Pengaruh waktu dan suhu reaksi grafting pada proses pembuatan maleated natural rubber. Jurnal Online Mahasiswa Bidang Teknik dan Sains, 1(2), 6P.
Socrates, G. (1994). Infrared characteristic group frequencies. Chichester : John Wiley \& Sons.

Suparto, D., Syamsu, Y., Cifriadi, A., \& Honggokusumo, S. (2009). Sifat teknis karet remah dengan viskositas Mooney dan kadar gel rendah. Prosiding Lokakarya Pemuliaan Tanaman Karet 2009. Bogor, Indonesia : Pusat Penelitian Karet.

Wati, R., Irdoni, H.S., \& Bahruddin. (2012). Modifikasi karet alam menjadi maleated natural rubber melalui proses grafting dengan variasi kadar maleat anhidrida dan temperatur. Jurnal Teknobiologi, Jurnal Ilmiah Sains Terapan, III(2), 111-114.

Zheleva, D. (2013). An attempt for correlation between Mooney viscosity and rheological properties of filled rubber compounds. Journal of Chemical Technology and Metalurgy, 38(3), 241246. 